\title{
DCTD wt Allele
}

National Cancer Institute

\section{Source}

National Cancer Institute. DCTD wt Allele. NCI Thesaurus. Code C53651.

Human DCT D wild-type allele is located in the vicinity of $4 q 35.1$ and is approximately 27 $\mathrm{kb}$ in length. This allele, which encodes deoxycytidylate deaminase protein, plays a role in thymidylate biosynthesis. 